Anita Gulczyńska, Mariusz Granosik*

\title{
Rewitalizacja w perspektywie społeczno-pedagogicznej
}

\section{Wprowadzenie}

Rewitalizacja to termin, który szczególnie w ostatnich latach coraz częściej pojawia się w dyskusjach politycznych, szczególnie na szczeblu samorządowym. Trudno też nie zauważyć jego rosnącej popularności w dyskursach naukowych różnych dziedzin. Bez wątpienia istotnym wyjaśnieniem tego stanu rzeczy są ogromne fundusze unijne oraz, co za tym idzie, inwestycje, które coraz skuteczniej są pozyskiwane i pożytkowane, póki co głównie przez miasta. Nie dziwi, w tym kontekście, że głównymi dyscyplinami zainteresowanymi rewitalizacją są architektura, budownictwo, ekonomia i zarządzanie, niekiedy geografia. Inwestycje finansowane ze środków unijnych muszą być jednak uzupełnione komponentem społecznym, dlatego w rewitalizację angażuje się również socjologia.

Wielkim nieobecnym na tym polu naukowej współpracy, a niestety i rywalizacji, jest pedagogika, w szczególności pedagogika społeczna. Brak perspektywy edukacyjnej czy wychowawczej nie pozostaje bez wpływu na kształt procesów rewitalizacyjnych, projektowanych i realizowanych w naszym kraju. W znacznej części są to zatem działania budowlano-architektoniczno-finansowe z doklejonym niekiedy na siłę modułem społecznym, ograniczającym się często do kilku akcji mających chwilowo, w okresie realizowania inwestycji, zmobilizować społeczność. W efekcie, przemiany estetyczne, inwestycyjne (np. generujące wzrost wartości nieruchomości), które przynoszą największą korzyść polityczną, dominują nad zmianami społecznymi, które z uwagi na brak doświadczenia i metod pracy społecznej ${ }^{1}$, traktowane są jako uzupełniające, wątpliwe, a nawet zbędne.

${ }^{*}$ Uniwersytet Łódzki, Wydział Nauk o Wychowaniu, Katedra Pedagogiki Społecznej.

${ }^{1}$ Nie znajdując lepszego odpowiednika, a częściowo również chcąc rewitalizować pedagogiczną tradycję, odwołujemy się tutaj do „pracy społecznej”, oryginalnego polskiego terminu 
Zdarzają się nawet przypadki, że cele społeczne rewitalizacji, zwykle nieoficjalnie, osiagane są poprzez przeniesienie rdzennych mieszkańców w inne części miasta, a w ich miejsce zakwaterowanie tych, którzy lepiej pasują do nowej przestrzeni urbanistycznej i są w stanie ekonomicznie utrzymać się w dzielnicy o „podwyższonej wartości nieruchomości”.

Co najmniej z perspektywy pedagogiki społecznej, a prawdopodobnie wszystkich nauk o wychowaniu, takie działania są niemal dokładnym zaprzeczeniem rewitalizacji, w której centralne miejsce zajmuje człowiek. Wszystko zaczyna się więc od społeczności, jej służy i na niej się kończy, dlatego ujęcie to bywa nazywane rewitalizacją humanistyczną. Nawet jednak nie przyjmując perspektywy społeczno-pedagogicznej, pominięcie lub niedocenienie wymiaru ludzkiego w projektowaniu zmian przestrzennych zwykle wcześniej czy później kończy się niepowodzeniem. Znane są przypadki choćby przywracania przez mieszkańców dawnego układu funkcjonalno-przestrzennego podwórka, bo zmiany zostały wprowadzone bez nich i co ważniejsze - bez właściwego zrozumienia symbolicznych aspektów przestrzeni, a więc lokalnej kultury.

Biorąc za punkt wyjścia powyższe obserwacje, wydaje się, że idea rewitalizacji, procesu niewątpliwie złożonego, międzyobszarowego i społecznie delikatnego, powinna być wzbogacona o perspektywę pedagogiki społecznej, w szczególności rozwijanej teoretycznie i metodycznie już co najmniej przez 80 lat pracy społecznej, której fundamentem od samego początku jest ożywianie aktywności społeczności poprzez jej własne siły (zasoby) i w kontekście jej własnej kultury. Trudno również przecenić dorobek pedagogów społecznych w zakresie animacji, która już na poziomie definicyjnym wykazuje analogie do procesów

Heleny Radlińskiej, mając świadomość, że prawdopodobnie nie jest on dobrze rozpoznawalny poza pedagogiką. Co więcej, często - na ogół nie do końca zasadnie - utożsamiany jest z „pracą socjalną" (na temat wzajemnych związków pracy społecznej i socjalnej (por. E. Marynowicz-Hetka, J. Piekarski, D. Urbaniak-Zając (red.), Pedagogika społeczna i praca socjalna. Przeglad stanowisk $i$ komentarze, Wyd. Śląsk, Katowice 1998). Innym wariantem popularyzowanym przez Centrum Aktywności Lokalnej, w szczególności przez Bohdana Skrzypczaka, jest „,praca społecznościowa”. Choć sam wspomniany autor uważa go za odpowiednik „community work”, to jednak odwołuje się wprost do polskiej tradycji społeczno-pedagogicznej (B. Skrzypczak, W kierunku społecznościowej pracy socjalnej. Edukacyjno-środowiskowe determinanty interwencji publicznej, CAL, Warszawa 2014, s. 33, przyp. 10, s. 50-53, 83-93). Wydaje nam się jednak, że „praca społecznościowa” jest jeszcze mniej rozpoznawalnym terminem niż „praca społeczna”.

${ }^{2}$ Być może tego typu działania będą nieco ograniczone w przyszłości z powodu podkreślenia w nowej ustawie o rewitalizacji konieczności zapobiegania „wykluczeniu mieszkańców obszaru rewitalizacji z możliwości korzystania z pozytywnych efektów procesu rewitalizacji, w szczególności w zakresie zasad ustalania wysokości czynszów" (Dz.U. z dnia 3 listopada 2015, poz. 1777, art. 40). Nie należy chyba jednak oczekiwać zmian zbyt optymistycznie, bowiem samorządy coraz rzadziej przemieszczają mieszkańców poprzez podnoszenie różnych opłat, a coraz częściej poprzez przekonywanie (z wykorzystaniem różnych argumentów) by mieszkańcy zgodzili się przenieść dobrowolnie. 
rewitalizacyjnych ${ }^{3}$. Odnajdujące swe początki w badaniu ,społecznych przyczyn niepowodzeń szkolnych"4 diagnozy środowiskowe zgromadziły na przestrzeni rozwoju tej dyscypliny akademickiej nie tylko metody i narzędzia kompleksowego rozpoznawania sposobów oddziaływania najbliższego środowiska dla różnorodnych sfer rozwoju (szczególnie nieletnich) jego mieszkańców, lecz także wypracowały w efekcie ich stosowania rzetelną, naukową wiedzę oraz wykładnię dla projektów jego społeczno-pedagogicznej optymalizacji.

Różnym wariantom pożytkowania współczesnych interpretacji tego ważnego dorobku w procesie rewitalizacji, przedstawionym z konieczności w skrótowej formie, poświęcony będzie niniejszy tekst.

\section{Cztery modele (dyskursy) rewitalizacji}

Według ustawy o rewitalizacji z 9 października 2015 r. jest ona definiowana jako ,proces wyprowadzania ze stanu kryzysowego obszarów zdegradowanych, prowadzony w sposób kompleksowy, poprzez zintegrowane działania na rzecz

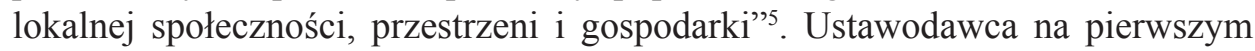
miejscu wymienia społeczność lokalną, ale z uwzględnieniem lokalnej przestrzeni oraz gospodarki. W dalszej części definiuje stan krytyczny jako „koncentrację negatywnych zjawisk społecznych w szczególności bezrobocia, ubóstwa, przestępczości, niskiego poziomu edukacji lub kapitału społecznego, a także niewystarczającego poziomu uczestnictwa w życiu publicznym i kulturalnym". W ustawie wymienieni są również ,interesariusze" procesu rewitalizacji, a więc ważne - z perspektywy ustawodawcy - siły społeczne, które powinny partycypować w zmianach. Wspomina się tu przede wszystkim mieszkańców, ponadto lokalne podmioty prowadzące działalność gospodarczą i społeczną, na końcu jednostki samorządowe i inne organy władzy?

${ }^{3}$ Analogia ta nasuwa się samoistnie, kiedy przyjmiemy rozumienie animacji za J. Żebrowskim, według którego oznacza ona „pobudzenie, ożywienie społeczności lokalnych (środowisk) w ich różnorodnych dziedzinach działalności. Animować to wnosić życie, zachęcać, rozpalać dodawać bodźca do podejmowania nowych inicjatyw, a więc ożywiać grupę, dodawać sił i odwagi do działania, pośredniczyć i zachęcać do uczestnictwa w życiu społecznym, udzielać wsparcia jakiejś osobie czy grupie w jej pracy nad sobą bądź nad rozwiązywaniem jakichś zadań” (J. Żebrowski, Wspótczesny wymiar animacji społeczno-wychowawczej i kulturalnej, [w:] J. Żebrowski (red.), Animacja kulturalna i społeczno-wychowawcza w środowiskach lokalnych, GTN, Gdańsk 2003, s. 17).

${ }^{4}$ H. Radlińska (red.), Społeczne przyczyny powodzeń i niepowodzeń szkolnych, Nasza Księgarnia, Warszawa 1937.

${ }^{5}$ Ustawa z dnia 9 października 2015 r. o rewitalizacji, Dz.U. z dnia 3 listopada 2015, poz. 1777, rozdz. 1 , art. 2 , pkt 1 .

${ }^{6}$ Tamże, rozdz. 3, art. 9, pkt 1.

${ }^{7}$ Tamże, rozdz. 1, art. 2, pkt 2. 
Polskie prawo wydaje się zmierzać w stronę podkreślania pierwszoplanowego znaczenia społecznego aspektu rewitalizacji, traktując kwestie urbanistyczno-architektoniczne jako konieczne ${ }^{8}$, ale tylko dopełniające. W ramach kwestii społecznych podkreślana jest partycypacja wszystkich interesariuszy, jednak przede wszystkim poprzez opiniowanie projektu i planu inwestycji (konsultacje społeczne). Zdecydowanie społecznocentryczny wydźwięk założeń ogólnych stoi $\mathrm{w}$ istotnej strukturalnej sprzeczności ze szczegółowymi wskazaniami ustawowymi, które już w przeważającej większości dotyczą kwestii gospodarczych, technicznych i architektonicznych. Można postawić hipotezę, że w tych ostatnich zakresach ustawodawca wiedział dokładnie, jak powinna wyglądać rewitalizacja, a w zakresie kwestii społecznych już tylko ogólnie (deklaratywnie, politycznie) wskazał, że to ważne. Co więcej, w całej ustawie nie pojawia się aspekt kształtowania przestrzeni wychowawczej (kluczowy z podejmowanej tu perspektywy). Nie jest też w żaden sposób pożytkowany dorobek pedagogiki społecznej, który umożliwiłby prawdopodobnie dookreślenie, a w niektórych punktach przeformułowanie społecznych komponentów rewitalizacji.

Obecne ramy prawne rewitalizacji w Polsce nie mogą oczywiście wyznaczać perspektywy społeczno-pedagogicznej, która jest przecież efektem konceptualizacji teoretycznych i kumulowanych przez wiele dziesiątków lat doświadczeń praktycznych. Warto jednak podkreślić, że kierunek, w którym zmierzają ostatnie zmiany, zbliża formalnie definiowaną rewitalizację do obszaru zainteresowań nauk o wychowaniu, otwierając im możliwość, a z naszej perspektywy nawet obowiązek, uczestniczenia $\mathrm{w}$ tym niezwykle ważnym dla społeczności procesie. Niezależnie jednak od punktu widzenia można założyć, że rewitalizacja jest kształtowana przez: projektantów technicznych (architektów, urbanistów, itd.), zarządców (władze gminne, inwestorów, koordynatorów/kuratorów programów głównie unijnych), społeczność lokalną (mieszkańców, lokalnych przedsiębiorców), wreszcie przez dyskursy publiczne i naukowe, które zdają się równie silnie, choć nie zawsze w ten sam sposób, kształtować wszystkie wcześniej wymienione podmioty. Różne układy dominacji wymienionych tu elementów składowych (dyskursy polityczne) przekładają się na odmienne założenia zarówno w zakresie natury rzeczywistości społecznej (dyskursy teoretyczne), jak i działania, które tę rzeczywistość miałyby przekształcać (dyskursy zmiany społecznej). Z tej perspektywy można wyróżnić cztery podstawowe modele rewitalizacji:

1) techniczno-zarządczy (dominujący w oficjalnych dokumentach, ustawach i praktyce);

${ }^{8}$ Aby dany obszar zakwalifikować jako zdegradowany i podlegający rewitalizacji, nie wystarczy wykazać jego kryzysowy stan z uwagi na negatywne zjawiska społeczne, ale dodatkowo muszą się tam ujawniać problemy gospodarcze albo środowiskowe, albo przestrzenno-funkcjonalne, albo techniczne (tamże, rozdz. 3, art. 9, pkt 2). 
2) ekonomiczno-społeczny (socjologiczny, społeczno-pedagogiczny, oparty na pracy socjalnej, animacji kulturalnej);

3) interpretatywno-refleksyjny (społeczno-pedagogiczny, oparty na pracy społecznej);

4) emancypacyjno-krytyczny (emancypacyjny, krytyczno-pedagogiczny).

Model techniczno-zarządczy odzwierciedla prawdopodobnie dominujące wyobrażenie społeczne rewitalizacji jako projektu przede wszystkim estetyczno-użytkowego. Tak postrzegana rewitalizacja zaczyna się od wizji czy projektu architektoniczno-urbanistycznego, który następnie jest stopniowo realizowany. Ogromna skala inwestycji materialnych wymusza na podmiocie realizującym (zwykle władzach lokalnych) zogniskowanie działań na: pozyskiwanie funduszy i zarządzanie nimi; rozwiązywanie często skomplikowanych własnościowych kwestii prawnych; godzenie odważnych i nowoczesnych wizji architektonicznych z możliwościami finansowymi, organizacyjnymi i czasowymi; rozwiązywanie problemów ludzkich (np. konieczności czasowej eksmisji). W efekcie kwestie społeczne traktowane są jako niechciany, ale jednak często konieczny element, by pozyskać, a potem skutecznie rozliczyć dotacje czy granty. Tak realizowana rewitalizacja jest typowym procesem zmiany sterowanej odgórnie, efektownej i szybkiej (efekty inwestycji widoczne są już po kilku latach), przez co bardzo atrakcyjnej politycznie. Niestety, z perspektywy społeczno-pedagogicznej jest to zmiana pozorna i krótkotrwała, ponieważ nie jest zakotwiczona w przekształceniu środowiska życia mieszkańców, właściwie nie dotyka problemów dla nich kluczowych. Co więcej, często traktowana jest przez mieszkańców jako arogancka ingerencja $\mathrm{w}$ ich przestrzeń, dlatego kończy się aktami obywatelskiego protestu z samowolnym przywracaniem dawnego porządku włącznie. Przemiany tego typu często niszczą lokalne kultury, bowiem ambitne plany architektoniczne są zwykle dostosowane bardziej do modnych "światowych" trendów niż wyrastających z lokalnej historii estetycznych preferencji mieszkańców. Powodzenie takiej rewitalizacji oceniane jest na podstawie podobieństwa efektu końcowego do wyjściowego projektu architektonicznego, a skutki takich przemian często stają się tzw. wizytówką miasta i są pokazywane na zdjęciach czy folderach reklamowych, o ile uda się zrobić takie zdjęcia bez mieszkańców, którzy zwykle tę estetykę psują.

Model ekonomiczno-społeczny odzwierciedla dominujące w dyskursie publicznym trendy kształtowania społeczeństwa obywatelskiego poprzez promowanie wartości (w tym wychowawczych) klasy średniej, z których najważniejszą jest edukacja i zaangażowanie w sprawy ogółu. W takim ujęciu trzonem rewitalizacji są działania społeczno-ekonomiczne, a ich pochodnymi - inwestycje infrastrukturalne. Te pierwsze są ważne, by ludzi wyrwać z ubóstwa, bezrobocia i nałogów oraz włączyć w krąg oddziaływania edukacji i kultury wyższej, te drugie - by dać im szansę życia na poziomie, czyli „po ludzku”. Tak rozumiana rewitalizacja jest 
bliska dominującym trendom we współczesnych naukach społecznych, takich jak socjologia, pedagogika czy geografia społeczna, w pewnym sensie jest to współczesna kontynuacja oświeceniowej idei „niesienia kaganka oświaty”. W znacznym stopniu jest to model wprowadzania zmiany odgórnie, jednak nie poprzez mechaniczne jej narzucenie (jak w poprzednim modelu), ale poprzez dopasowywanie (edukowanie) społeczności lokalnej do planowanych przedsięwzięć.

Model interpretatywno-refleksyjny w odróżnieniu od poprzedniego bazuje na zmianie oddolnej. Ramy te wyznaczane są teoretycznie przez dosyć powszechnie akceptowany konstruktywizm społeczny konkretyzujący się współczesnymi interpretacjami społeczno-pedagogicznej koncepcji przekształcania środowiska jego własnymi siłami oraz socjologicznej teorii społecznego tworzenia rzeczywistości. Rewitalizacja opiera się tu od samego początku na współpracy z mieszkańcami, której celem jest obudzenie ich własnych inicjatyw ugruntowanych w lokalnej kulturze, tak by sami przekształcali swoje środowisko życia. Podjęcie takich działań wymaga specjalnej diagnozy (nazywanej interpretatywną9) pozwalającej zrozumieć wewnętrzną logikę organizacji życia społeczności. Zmiany architektoniczne i przestrzenne są jedynie efektem zmiany społecznej i bazują na estetycznych czy pragmatycznych perspektywach mieszkańców (architektura społecznie ugruntowana, geobiografia). Wyraźną słabością takiego modelu rewitalizacji może być powolność zmian społecznych i ich nieprzewidywalny rezultat, co utrudnia ocenę postępu. Właściwie głównym wskaźnikiem ewaluacyjnym jest przyrost sił społecznych zaangażowanych w działanie.

Model krytyczno-emancypacyjny odzwierciedla dyskusje i reorientacje związane ze współczesnym funkcjonowaniem społeczeństw oraz roli nauk społecznych. Chociaż zakreślane dalej perspektywy są zdecydowanie mniejszościowe, to jednak na tyle inspirujące, że - naszym zdaniem - warte przedstawienia. Przyjmuje się tu założenie, że większość problemów społecznych nie jest głównie skutkiem niedostosowania czy defektu jednostek, ale często efektem strukturalnych społecznych uwarunkowań, na które wspomniane jednostki nie mają żadnego wpływu. Nie wystarczy zatem zbudować bliżej szkołę czy więcej miejsc pracy, ale trzeba zmienić uwarunkowania, które skutecznie defaworyzują daną grupę. W ujęciu emancypacyjnym praca społeczna to nie tylko budzenie sił utajonych w mikroświatach społecznych, lecz także analiza i przekształcanie makrospołecznych uwarunkowań defaworyzacji (empowerment strukturalny), bo dopiero taka zmiana daje nadzieję autentycznego uwolnienia

${ }^{9}$ Diagnostyka interpretatywna, w odróżnieniu od normatywnej (obiektywnej), podejmowana jest z perspektywy intersubiektywnej, a jej rezultaty mają z zasady postać jakościową. Zagadnienie to będzie nieco rozwinięte $\mathrm{w}$ dalszej części rozdziału, już teraz jednak warto zauważyć, że taki sposób opisu rewitalizowanej przestrzeni słabo mieści się w przywoływanej ustawie o rewitalizacji, mimo deklaracji jej społecznego nachylenia. Ustawodawca zdecydowanie preferuje „obiektywne i weryfikowalne mierniki i metody badawcze" (tamże, rozdz. 1, art. 4.1). 
tych grup ${ }^{10}$. Rewitalizacja nie może się zatem ograniczać do procesów zachodzących lokalnie, ale musi również obejmować oddziaływanie na całe społeczeństwo, czyli w praktyce - na dyskursy kształtujące świadomość społeczną. Jest zatem rodzajem społecznej edukacji (uczą się nie tylko grupy defaworyzowane, lecz także wszyscy pozostali) albo dialogu. Nie chodzi o to, żeby przekonać mniejszość do poglądów i racji większości, ale by dyskursy mniejszościowe nie były dyskryminowane. $\mathrm{Z}$ jeszcze bardziej radykalnej perspektywy krytycznej rewitalizacja może być postrzegana jako narzędzie wprowadzania władzy do obszarów, które się jej skutecznie opierają. Nie chodzi tu wyłącznie o osobową władzę polityczną, ale o znacznie bardziej wysublimowane jej formy ukryte pod postacią np. obywatelskiej podmiotowości, z czego wynikają ciekawe konkluzje w zakresie tworzenia programów rewitalizacyjnych, szczególnie wtórnych zagrożeń, jakie mogą stwarzać.

$\mathrm{Z}$ wyjątkiem pierwszego modelu, wszystkie pozostałe opisują różne perspektywy działania społeczno-pedagogicznego, dlatego bardziej szczegółowo odniesiemy je do założeń samej pedagogiki społecznej, wskazując miejsce pedagoga społecznego w tych przemianach.

\section{Rewitalizacja w perspektywie społeczno-pedagogicznej}

Bardzo wielowątkowy dorobek Heleny Radlińskiej, twórczyni polskiej pedagogiki społecznej, zaowocował na przestrzeni lat bardzo różnymi jego przetworzeniami ${ }^{11}$. Nie inaczej jest $\mathrm{w}$ kontekście procesów rewitalizacji miast. Choć opracowania pożytkujące źródłowe koncepcje społeczno-pedagogiczne w tym zakresie są wciąż nieliczne, to jednak można w nich znaleźć interpretacje koncepcji kultury, środowiska niewidzialnego czy pracy społecznej, zorientowane bardziej normatywnie ${ }^{12} \mathrm{i}$ interpretatywnie, a momentami nawet emancypacyjno-krytyczne $^{13}$. Żeby nie powielać dostępnych opracowań, warto jedynie zauważyć, że w polskiej pedagogice społecznej dosyć powszechnie przyjmuje się przestrzenny

${ }^{10}$ Szerzej o empowermencie, w tym strukturalnym, traktują opracowania: J. Szmagalski, Teoria pracy socjalnej a ideologia i polityka społeczna - przykład amerykański, Wydawnictwo Żak, Warszawa 1996, s. 414; M. Granosik, A. Gulczyńska, Empowerment i badania w pracy socjalnej, [w:] A. Gulczyńska, M. Granosik (red.), Empowerment w pracy socjalnej: praktyka i badania partycypacyjne, seria Nowa Praca Socjalna, Centrum Rozwoju Zasobów Ludzkich, WYG International, Warszawa 2014, s. 16-18.

${ }^{11}$ Por. M. Cichosz, Pedagogika społeczna w Polsce w latach 1945-2005, Wyd. Adam Marszałek, Toruń 2006.

${ }^{12} \mathrm{~T}$. Wilk, Rewitalizacja społeczna poprzez wspótczesna sztukę teatralnq w ocenie reprezentantów (twórców i odbiorców) sztuki dramatycznej Legnicy, Nowej Huty i Wałbrzycha, Wydawnictwo Uniwersytetu Śląskiego, Katowice 2010, s. 76-82.

${ }^{13}$ A. Gulczyńska, ,Chłopaki z dzielnicy”. Studium społeczno-pedagogiczne z perspektywy interakcyjnej, Wydawnictwo Uniwersytetu Łódzkiego, Łódź 2013. 
model wychowania. Właściwie w całej tradycji wywodzącej się z dziedzictwa Heleny Radlińskiej ${ }^{14}$ nie tyle podkreślane jest samo wychowanie (kluczowe dla całej pedagogiki), ile organizacja środowiska wychowawczego ${ }^{15}$, które jest zawsze rodzajem przestrzeni. W fizycznym wymiarze owej przestrzeni zagadnienie środowiska wprost sytuuje się w bieżących dyskursach rewitalizacyjnych (również w aspekcie infrastrukturalno-technicznym, czego dalej nie będziemy rozwijać), natomiast $\mathrm{w}$ zakresie symbolicznym (niewidzialnym) ${ }^{16}$ jest rodzajem wyzwania, inspiracji do - używając języka Foucaulta - przeformatowania porządku tych dyskursów, co jest również jednym z celów niniejszego rozdziału.

Miasto, z podjętej tu perspektywy społeczno-pedagogicznej, to zatem lokalny układ utajonych, aktywnych, ożywionych sił ludzkich, a więc pewnych lokalnych potencjałów tkwiących w jednostkach, ale również w społeczności czy nawet społeczeństwie.

Drugim, niezwykle ważnym w kontekście rewitalizacji motywem jest usytuowanie człowieka w centrum zainteresowania ${ }^{17}$. W odróżnieniu od większości nauk społecznych, w których podstawowymi kategoriami pojęciowymi są: jednostka, aktor, podmiot gospodarczy, pedagogika społeczna pozostała przy chyba najbardziej humanistycznym wariancie, jakim jest ,człowiek”. Już sam ten fakt skupiania zainteresowań na tak szeroko (wręcz holistycznie) zakreślonej kategorii, na którą składa się wymiar biologiczny, społeczny i kulturowy w połączeniu z wielodyscyplinarną

${ }^{14}$ Przedstawiana dalej konceptualizacja, choć bazuje na źródłowych ideach Heleny Radlińskiej, nie jest jej prostym przetworzeniem. Współczesne odczytywanie perspektywy społeczno-pedagogicznej jest efektem złożonych historycznych i współczesnych procesów interpretacyjnych składających się na naukowy dyskurs pedagogiki społecznej w Polsce. Znaczna część tego dyskursu nie opiera się na systemowej rekonstrukcji myśli założycielki, ale wytwarza się w procesie wielowarstwowego nakładania fragmentów jej twórczości na inne, zwykle bardziej współczesne, niekiedy modne konceptualizacje, co bywa ciekawe i ożywcze, ale nierzadko również dyskusyjne czy nawet nieuprawnione.

${ }^{15}$ Pomijamy w tym miejscu, inspirowaną często literaturą niemiecką i koncepcją świata przeżywanego, bardzo interesującą krytykę „środowiska” jako centralnej kategorii społeczno-pedagogicznej (por. D. Urbaniak-Zając, Koncepcja ,'środowiska” w teorii pedagogiki społecznej Aleksandra Kamińskiego a idea „Lebenswelt”, [w:] E. Marynowicz-Hetka, H. Kubicka, M. Granosik (red.), Aleksander Kamiński i jego twórczość pedagogiczna. Dyskusja o przeszłości wobec teraźniejszości i przyszłości, Wydawnictwo Uniwersytetu Łódzkiego, Łódź 2004). Konkluzje tego dyskursu krytycznego są niezwykle ważne dla konstruowania interpretatywnych i emancypacyjnych modeli rewitalizacji, ale ograniczony rozmiar rozdziału nie daje szansy na rozwijanie wszystkich wątków.

${ }^{16}$ Oczywiście we współczesnym dyskursie społeczno-pedagogicznym można znaleźć znacznie więcej wymiarów przestrzeni: interakcyjna, interpretacyjna, dyskursowa, komunikacyjna, cyberprzestrzeń itd.

${ }_{17} \mathrm{~W}$ interpretacji Arkadiusza Żukiewicza podstawowe założenia pedagogiki społecznej Heleny Radlińskiej, np. koncepcję sił ludzkich, można wręcz ,identyfikować z personalistycznym podejściem do człowieka jako fenomenu" (por. A. Żukiewicz, Wprowadzenie do ontologii pracy społecznej. Odniesienia do społeczno-pedagogicznej refleksji Heleny Radlińskiej, Wyd. UP, Kraków 2009, s. 95 i n.). Autor ten, w odróżnieniu od prezentowanej dalej perspektywy interpretatywnej, idzie w stronę aksjologicznie normatywnej filozofii chrześcijańskiej. 
koncepcją bazy teoretycznej (nauka na skrzyżowaniu nauk) otwiera możliwość oryginalnej konceptualizacji samej rewitalizacji, a także pojęć dodatkowych, takich jak miasto czy przestrzeń. Miasto to ludzie, a konkretniej ich działania (w tym komunikacyjne i interpretacyjne). Same - używając języka Heleny Radlińskiej - urzq̨dzenia kultury „byłyby martwe, gdyby nie ożywiały ich ruchy społeczne”"18.

W tradycji społeczno-pedagogicznej idea pracy społecznej, na skutek uwarunkowań historycznych, często wiązana jest z edukacją do wolności. Sama Helena Radlińska, analizując proces rewitalizowania idei demokracji w Polsce, podkreślała znaczenie tajnych stowarzyszeń, których zadaniem ma być działanie edukacyjne ${ }^{19}$, pisze: ,jedynym środkiem (ożywienia ludu) jest święte wyobrażenie swobody, którym rozgrzać potrzeba serca. Do wolności dochodzi się - oświatą. Kiedy stanie się światło dla ludu, stanie się zarazem i wolność. Główną oświata, potrzebną dla zwycięstwa demokracji: pojmowanie praw człowieka" ${ }^{20}$.

Rewitalizacja w świetle ogólnie przedstawionych założeń pedagogiki społecznej ma odwrócony - $\mathrm{w}$ stosunku do podejścia techniczno-zarządczego - porządek, bowiem zaczyna się od człowieka i na nim kończy, a wymiary organizacyjne, techniczne czy infrastrukturalno-architektoniczne pełnią jedynie funkcje pomocnicze, są raczej pochodną rewitalizacji społeczności² ${ }^{21}$. Dalsze uszczegółowienie tej refleksji wiązać się jednak będzie z koniecznością przyjęcia bardziej normatywnej, interpretatywnej albo emancypacyjnej perspektywy interpretacyjnej, wyznaczając bardzo umowny podział na rewitalizację społeczną, humanistyczną oraz polityczną.

\section{Rewitalizacja społeczna (model społeczno-ekonomiczny)}

Rewitalizacja rozumiana jako proces społeczno-ekonomiczny odnajduje uzasadnienia i metodyczne inspiracje do działań w środowiskach lokalnych w koncepcjach teoretycznych wyrażających edukacyjną funkcję środowiska życia oraz

${ }^{18}$ H. Radlińska, Pedagogika społeczna, Zakład Narodowy im. Ossolińskich, Wrocław 1961, s. 290 .

${ }^{19}$ Przedstawioną tu myśl Radlińskiej można, jak wiele jej idei, interpretować normatywnie lub interpretatywnie czy nawet emancypacyjnie, podkreślając albo motyw edukowania ludu do wyższych wartości, albo uświadamiania mu jego uprawnień - praw człowieka, które dają szanse na wyzwolenie. Nic więc dziwnego, że dorobek jednej badaczki może stać się uzasadnieniem kilku różnych ujęć rewitalizacji i powiązanych z nimi koncepcji działania.

${ }^{20}$ H. Radlińska, Z dziejów pracy społecznej i oświatowej, Zakład Narodowy im. Ossolińskich, Wrocław 1964.

${ }^{21}$ Warto zauważyć, że również w innych dyscyplinach zainteresowanych rewitalizacją coraz częściej, choć wciąż rzadko, dochodzą do głosu podejścia bardziej „humanistyczne”: socjologia interpretatywna, krytyczne koncepcje zarządzania, goebiografia, zaangażowana społecznie architektura itp. Szczególnie ciekawe jest włączanie idei środowiska życia (społecznego czy wychowawczego) do nauk. Por. J. Kaczmarek, Geobiografia - historie życia a studia nad migracjami, „Acta Universitatis Lodziensis. Folia Geographica Socio-Oeconomica” 2004, nr 5. 
w wybranych koncepcjach społeczno-wychowawczej i kulturalnej animacji środowiska ${ }^{22}$.

Pedagogika społeczna dysponuje dorobkiem badawczym i doświadczeniami praktycznymi skoncentrowanymi wokół związku jakości lokalnych systemów wsparcia edukacyjno-społecznego (instytucje edukacyjne, opieki zdrowotnej czy służb społecznych) a rozwojem biosocjokulturalnym mieszkańców danego terytorium. Teoretycznym zapleczem takich eksploracji była i jest koncepcja środowiska Aleksandra Kamińskiego oparta na trójpodziale jego czynników na przyrodnicze, społeczne i kulturowe ${ }^{23}$. Podkreślając w swej koncepcji równouprawnienie tych kategorii, badacz wyodrębniał je z otoczenia rozumianego jako byt złożony z obiektywnie istniejących zasobów. O ich realności stanowi fakt oddziaływania na podmioty w nim funkcjonujące. Dając silną podstawę badaniom oddziaływań poszczególnych elementów środowiska życia na kierunek i poziom rozwoju mieszkańców, nurt ten zainspirował poniekąd rozwój modelowych ujęć środowisk wychowawczych, czyli odrębnych środowisk społecznych tworzonych na potrzeby przygotowania podmiotów do określonych ról społecznych ${ }^{24}$.

Dały one początek kompleksowym diagnozom społeczno-pedagogicznym prowadzonym w środowiskach lokalnych, w których aspekt organizacyjno-dystrybutywny jest równie silnie eksponowany, co dokonane przez pedagogów społecznych (często wspólnie z mieszkańcami), rozpoznanie sił i przeszkód w procesie tworzenia w obrębie badania lokalnego środowiska wychowawczego.

W ich założeniach (sformułowanych expressis verbis bądź zrekonstruowanych w analizie struktury obrazu diagnostycznego i kierunków proponowanych zmian w terenie objętym badaniem) odnaleźć można akcenty myślenia systemowego, np. badania systemu wsparcia społecznego w miejscu zamieszkania,

${ }^{22}$ Istotą działań animacyjnych jest ożywienie ukrytych potencjałów ludzkich, społecznych i kulturowych przy prymarnym znaczeniu aktywizacji mieszkańców w dokonującej się zmianie lokalnej. Różna jednak może być ich celowość. Zważywszy na odnoszenie się w społeczno-ekonomicznym modelu rewitalizacji do perspektywy normatywnej w konstruowaniu celowości przekształceń rewitalizacyjnych, dla zobrazowania miejsca pedagogiki społecznej w tym modelu rewitalizacji wybraliśmy i zaprezentowaliśmy koncepcję działań animacyjnych reprezentującą paradygmat logicznie spójny z tym modelem.

${ }^{23}$ A. Kamiński, Funkcje pedagogiki społecznej, PWN, Warszawa 1973, s. 28-30.

${ }^{24}$ Odwołujemy się tutaj do klasycznej definicji środowiska wychowawczego Floriana Znanieckiego (F. Znaniecki, Socjologia wychowania, Warszawa 1973, s. 64), mając świadomość, że w obszarze pedagogiki społecznej jest ono nie tylko jednym z kluczowym pojęć, lecz także koncepcją znaczącą w dyskursie wokół tożsamości tej dyscypliny akademickiej. Pedagogikę społeczną jako teorię środowiska ujmował m.in. Stanisław Kawula, widząc w swej dyscyplinie akademickiej „Zarazem pedagogiczną teorię i praktykę środowiska [...], gdyż traktuje ona wszelkie instytucje społeczne (formalne i nieformalne) jako środowiska ludzkiego życia i usiłuje dostrzec w nim siły i dynamizmy lub sugerować intencjonalność pracy wychowawczej, aktywizować jego zasoby / potencjały/" (S. Kawula, Pedagogika społeczna i jej wyzwania u progu XXI w., [w:] E. Marynowicz-Hetka, Pedagogika społeczna. Podręcznik akademicki, t. 2, PWN, Warszawa 2007, s. 52). 
badania pozaszkolnej oferty edukacyjnej czy infrastruktury osiedla pod względem organizacji czasu wolnego. Troskę o edukacyjną funkcję środowiska lokalnego odnajdujemy też w pogłębionych diagnozach wybranego elementu systemu organizacji i instytucji społeczno-wychowawczych, w którego optymalizacji diagności upatrują szans na zwiększenie efektywności edukacyjnych oddziaływań W środowisku lokalnym ${ }^{25}$.

Najbardziej powszechnymi rezultatami badań tej orientacji są fukcjonalno-strukturalne opisy pojedynczych komponentów środowiska wychowawczego (szkoły lokalnej, domu kultury, świetlicy środowiskowej etc.) czy lokalnego systemu instytucji wychowawczych, wraz z rekonstrukcją egzo- i makrosystemowych uwarunkowań ich oddziaływań oraz przesłankami usprawnienia ich funkcjonowania ${ }^{26}$. To diagnozy definiujące zakres potrzebnych zmian w lokalnym środowisku wychowawczym, np. potrzebę optymalizacji współpracy elementów systemu, potrzebę jego wzbogacenia o nowe elementy, odpowiadające dynamice zmian lokalnych czy wskazanie kierunków optymalizacji w samych już istniejących podsystemach bądź pożądanych zmian makrosystemowych.

Wspólnym mianownikiem takich badań oraz implementacji potrzebnych zmian są działania podejmowane przez osoby niemieszkające $\mathrm{w}$ badanym środowisku życia (sąsiedztwie, osiedlu, wsi etc.), które, kontrolując ważne zasoby instytucjonalne tam zlokalizowane, starają się dostosować je do kompleksowych potrzeb mieszkańców, nierzadko uwzględniając ich zdanie w diagnozie, planowaniu i samej pracy środowiskowej.

${ }^{25}$ Problematykę optymalizacji działania wybranych elementów środowiska wychowawczego podejmują m.in.: J. Wołczyk, M. Winiarski (red.), Szkoła otwarta - rzeczywistość i perspektywy, PWN, Warszawa 1976; J. Wołczyk, Z badań nad zbiorczq szkoła gminna, Zeszyty Naukowe nr 18 „Prace Wydziału Pedagogicznego”, WSP, Szczecin 1976; B. Chmielowski, Pałac młodzieży jako placówka wychowania (Wychowanie do wczasów w placówce typu Pałac Młodzieży), Gabinet Metodyczny - Pałac Młodzieży w Katowicach, Katowice 1971; I. Lepalczyk (red.), Stowarzyszenia społeczne jako środowisko wychowawcze, PWN, Łódź 1973; E. Trempała, Pedagogiczna dziatalność wychowawców nieprofesjonalnych w środowisku lokalnym, Wyższa Szkoła Pedagogiczna w Bydgoszczy, Bydgoszcz 1988; E. Marynowicz-Hetka, Szkoła jako instytucja pomocy w rozwoju, „Chowanna” 1989, z. 1.

${ }^{26}$ Inspiracje do projektowania kompleksowych diagnoz wychowawczej funkcji środowisk lokalnych odnajdujemy m.in. w pracach: E. Trempała, Integracja podstawowych środowisk wychowawczych a rezultaty pracy pedagogicznej szkoły, Państwowe Wydawnictwo Naukowe, Warszawa 1969; I. Lepalczyk, W. Pawłowska, Teoria i organizacja pracy środowiskowej w osiedlu mieszkaniowym, TWWP, Warszawa 1970; M. Śnieżyński, Działalność opiekuńczo-wychowawcza w osiedlu, Wydawnictwa Szkolne i Pedagogiczne, Warszawa 1981; E. Trempała, M. Balcerek, M. Winiarski (red.), Opieka i wychowanie w osiedlu mieszkaniowym, Wydawnictwa Szkolne i Pedagogiczne, Warszawa 1981; M. Ciczkowska-Giedziun, Dzieci i młodzież w osiedlu miejskim: diagnoza i rozwiqzania modelowe, Olsztyńska Szkoła Wyższa im. Józefa Rusieckiego, Olsztyn 2002; W. Dykcik, Stanisława Kowalskiego (1904-1991) koncepcja doskonalenia systemu wychowawczego w środowisku, [w:] S. Kawula (red.), Pedagogika spoleczna. Dokonania - aktualność - perspektywy, Wyd. Adam Marszałek, Torun 2001. 
Włączenie doświadczenia pedagogów społecznych z organizacją środowisk wychowawczych do konceptualizacji procesów rewitalizacyjnych byłoby jednoznaczne z nadaniem tym procesom znaczenia ponadlokalnego, wyrażającego się służbą w procesie urealniania idei społeczeństwa wychowującego. W takiej perspektywie planowanie procesu rewitalizacji „miękkiej” pozwoliłoby uniknąc kosztownego tworzenia nowych placówek środowiskowych, opierając koncepcję zmian na istniejących komponentach lokalnych systemów wsparcia edukacyjno-społecznego i ich modernizacji, udrażnianiu na potrzeby społecznego ożywiania kolejnych sąsiedztw miejskich, by komplementarnym wysiłkiem pełniej służyły idei pomocy w rozwoju ich mieszkańców.

W przeciwieństwie do systemowego ujęcia procesu tworzenia i udoskonalania środowiska wychowawczego w miejscach zamieszkania, społeczno-pedagogiczne doświadczenia $\mathrm{w}$ zakresie animacji środowiskowej realizują zmianę edukacyjnej funkcji środowiska lokalnego poprzez wprowadzanie działań aktywizujących samych mieszkańców. Są one prowadzone na rzecz odtwarzania, przywracania dawnego porządku normatywnego (niekiedy budowania nowego).

$\mathrm{Na}$ tle całego bogactwa społeczno-pedagogicznych prac poświęconych animacji wyodrębniła się skromna póki co refleksja na temat roli działań animacyjnych $\mathrm{w}$ procesie rewitalizacji, np. realizowanych poprzez sztukę teatralną, co szczegółowo analizuje w swojej obszernej pracy Teresa Wilk ${ }^{27}$. Dla reprezentantów tego ujęcia, odwołującego się często wprost do socjologicznych koncepcji strukturalno-funkcjonalnych czy kapitału kulturowego (społecznego),

pojęcie „rewitalizacja społeczna” jest procesem zorientowanym na wprowadzenie określonych zmian, odbudowę pożądanych wartości, struktur funkcjonujących w przeszłości, jest ożywieniem - przywróceniem do życia, sprawności - przestrzeni ludzkiej egzystencji. Jest działaniem pragmatycznym, przywracającym i regenerującym więzi społeczne, a także pożądane postawy. [...] Aby działania zainicjowane w tym procesie mogły przynieść oczekiwane rezultaty, niezbędne jest określenie zasad i warunków. [...] Istotną kwestią jest określenie kapitałów - społecznych, edukacyjnych, kulturowych, jakimi dysponuje środowisko, wyodrębnienie instytucji, które w znaczący sposób mogą włączyć się w podejmowane inicjatywy oraz uaktywnienie czynników motywujących przedstawicieli lokalnej społeczności do zaangażowania się w działania tworzące bezpieczną przestrzeń ${ }^{28}$.

Niezależnie czy powyższe propozycje odwołują się w uzasadnieniach działań do rozumienia środowiska jako bytu zewnętrznego wobec jego uczestników explicite czy implicite, tym co je łączy jest równoważnie ich normatywności jednoczesnym akcentowaniem znaczenia ,sił społecznych" i ,sił ludzkich” organizowanych jednak w zewnętrznie ustalonym kierunku (np. orientowanych na uczestnictwo w kulturze/edukacji wyższej).

\footnotetext{
${ }^{27} \mathrm{~T}$. Wilk, Rewitalizacja spoteczna poprzez wspótczesnq sztukę teatralnq...

${ }^{28}$ Tamże, s. 8.
} 


\section{Rewitalizacja humanistyczna (model interpretatywny)}

Interesującą propozycję namysłu nad sposobami odzwierciedlania interpretatywizmu w społeczno-pedagogicznym ujęciu rewitalizacji daje wprowadzenie do dyskursu społeczno-pedagogicznego kategorii „miejsca”29. Można je rozumieć jako oswojoną i zadomowioną część przestrzeni, dla kontrastu utożsamianą $\mathrm{z}$ brakiem granic i wolnością ${ }^{30}$. Odczucie przestrzeni jako własnej nadaje miejscu znaczenie konstrukcji biograficznej. Jej granice i struktura substancjalizują się w perspektywie indywidualnych karier życiowych, tworzonych jednak społecznie, we wspólnym doświadczaniu codzienności, w której dzieją się sprawy ważne. Zdaniem Marii Mendel

jeżeli świat rozumieć, jako bliżej nieokreśloną, przeczuwaną jedynie, niedotkniętą przestrzeń, „,nasz świat”, będzie miejscami pamiętającymi naszą obecność, noszącymi jej ślady, znaczącymi to, co o nich myślimy, mówimy snując życiowe narracje, żyjąc własne życia. [...] Najbliższe nam fragmenty rzeczywistości budują nas najbardziej ${ }^{31}$.

Wprowadzenie pojęcia „miejsce” do dyskursu pedagogicznego w połączeniu z przywołaniem myśli społeczno-pedagogicznej nadało nowe znaczenie pracy społecznej. W perspektywie interpretatywnej pojęciem tym obejmowane byłyby tylko te zmiany lokalne, w projektach których odzwierciedla się szacunek do tożsamości jej uczestników, ich społecznego stawania się w kontekście małych ojczyzn, które „dostarczają nam źródłowej orientacji ‘bycia sobą' i pomimo tego, iż nie stanowią stabilnego fundamentu naszej tożsamości, udzielają ochrony 'przed byciem jedynie tułaczami'”'32. Miejsce rozumiane jako „przestrzeń znacząca” nie może być zmieniane poprzez nasycanie go znaczeniami obcymi, zewnętrznymi wobec odczuć samych podmiotów. Praca społecznościowa zorientowana na wspomaganie rozwoju mieszkańców i edukację w kierunkach „obcych” lokalnej perspektywie, niezależnie od zaangażowanego w nich udziału samych „tubylców”, nie mieści się w ramach pedagogiki miejsca. Wymaga bowiem „wykorzenienia”, skonstruowania kontekstu sprzyjającego doświadczeniu ontologicznej pustki, by się ,zakorzenić ponownie, w lepszej jednak glebie, użyźnianej uniwersalnymi

${ }^{29}$ Inicjatorką oraz chyba najbardziej aktywną propagatorką pedagogiki miejsca w Polsce jest Maria Mendel (por. M. Mendel (red.), Pedagogika miejsca, Wyd. Naukowe DSWE, Wrocław 2006).

${ }^{30}$ Odnosimy się tutaj do rozdziału miejsca i przestrzeni w koncepcji Yi-Fu Tuana, na którego powołuje się Maria Mendel w pracy na temat założeń „pedagogiki miejsca”. M. Mendel, Wstęp, [w:] M. Mendel (red.), Pedagogika miejsca, s. 9-10.

${ }^{31}$ M. Mendel, Pedagogika miejsca i animacja na miejsce wrażliwa, [w:] M. Mendel (red.), Pedagogika miejsca, s. 22.

${ }^{32}$ A. Męczkowska, Locus educandi. Wokót problematyki miejsca w refleksji pedagogicznej, [w:] M. Mendel (red.), Pedagogika miejsca, s. 40. Męczkowska odnosi się tutaj do koncepcji „miejsc źródłowej orientacji” Ricouera. P. Ricouer, Egzystencja i hermeneutyka: rozprawy o metodzie, tłum. E. Bieńkowska, Instytut Wydawniczy PAX, Warszawa 1975. 
wartościami kultury"33. Pedagogice miejsca bliskie więc będą takie formy pracy w środowisku otwartym, które - odnosząc się do poczucia realności uczestników społeczności lokalnych - wynoszą uznanie ,edukacyjnej roli miejsca doczesnego, obejmującego realne egzystencjalne doświadczenie podmiotów ponad «mit pedagogicznej wędrówki do ziemi obiecanej»" ${ }^{34}$.

Jakie przesłanki dla projektów rewitalizacyjnych mogą wynikać z takich (niezwykle syntetycznie wyłożonych) założeń pedagogiki miejsca?

Pierwsza odnosi się do sposobu manifestowania się w rewitalizacji rozumienia symbolicznej „własności” miejsca. Ponieważ nie istnieje ono poza podmiotami społecznie je tworzącymi, to oni są uznani za ekspertów do spraw jego przekształcania. W diagnostycznej warstwie procesu rewitalizacji ta zmiana paradygmatu wyrażać się będzie przyjęciem wewnętrznej perspektywy oglądu interesujących zjawisk, natomiast w warstwie urzeczywistniania wynikających zeń zmian - uznaniem uczestników za kluczowych jej realizatorów i beneficjentów. To oni są gospodarzami przestrzeni, stąd wszelkie zmiany powinny następować dopiero po dogłębnym wniknięciu w logikę ich racjonalności, zrozumieniu kluczowych wzorów użytkowania terytorium i odkryciu uważnionych w narracjach życiowych mieszkańców jego elementów. Koncepcja diagnostyki interpretatywnej rozwijana w Uniwersytecie Łódzkim przez zespół pracowników Katedry Pedagogiki Społecznej wydaje się wiele wnosić do rozumienia wzajemnych związków pomiędzy interpretatywnymi koncepcjami teoretycznymi, logicznie spójnymi z narzędziami diagnozy środowiskowej, a koncepcją procesów rewitalizacyjnych wrażliwych na „miejsce”35.

Druga kwestia jest natomiast zarys interpretatywnie zorientowanej roli pedagoga społecznego w procesach rewitalizacji. Jej celowość wyrażałaby się w różnicowaniu, a nie ujednolicaniu społecznej przestrzeni miasta. Rewitalizacja zdegradowanych obszarów miejskich w tym modelu nie jest bowiem narzędziem implementacji kanonów mainstreamowej estetyki mającej czynić miasto bezimiennym acz interesującym dla zewnętrznego kapitału. Nie jest również narzędziem re-edukacji, re-adaptacji czy re-socjalizacji tych, którym przypisuje się odpowiedzialność za aktualny stan tych obszarów, dokonywanych poprzez nasycenie ich miejsca kulturą i stylem życia podmiotów napływowych, a niekiedy nawet tylko wpływowych (niemieszkających w tej przestrzeni, ale mających

${ }^{33}$ A. Męczkowska, Locus educandi..., s. 38.

${ }^{34}$ Tamże.

${ }^{35}$ Mam tutaj na uwadze prace zespołu badawczego, w skład którego wchodzą: Mariusz Granosik, Anita Gulczyńska, Anna Jarkiewicz i Małgorzata Kostrzyńska. Więcej o głównych założeniach diagnostyki interpretatywnej w: M. Granosik, Praca socjalna w perspektywie interpretatywnej: teoria, diagnoza, działanie, [w:] A. Skowrońska (red.), Nowe ujęcia znanych problemów pomocy społecznej, IRSS, Warszawa 2013; tenże, Diagnostyka interpretatywna: między jakościowq metodologiq i praktykq, [w:] M. Szpunar (red.), Badania w pracy socjalnej, ANWI, Gdańsk 2015. 
władzę). Pedagog społeczny-animator, wykorzystując „działanie miejscem” lub „działanie miejsca" ${ }^{36}$, kierując się przesłankami konstruktywizmu, będzie ożywiał przestrzeń której intersubiektywne odczucie wypracuje w sobie w przebiegu pogłębianej i długoterminowej relacji (nie zaś jednorazowych, często markujących demokrację, konsultacjach społecznych) z jej symbolicznymi właścicielami. Zrozumienie każdej „lokalności”, którym dzielić się będzie z innymi podmiotami odpowiedzialnymi za rozwój przestrzeni, może dopiero stać się punktem odniesienia dla projektowanych i wspólnie z mieszkańcami wprowadzanych zmian rewitalizacyjnych. Takie działania w skali całego miasta służyłyby jego hybrydyzacji, dokonującej się z szacunkiem dla lokalnych historii, kultury i racjonalności, ucieleśniając ideał miasta wszystkich obywateli ${ }^{37}$.

Rewitalizacyjna praca społeczna jest więc, zgodnie $\mathrm{z}$ jedną $\mathrm{z}$ interpretacji koncepcji Heleny Radlińskiej, działaniem (oddziaływaniem) pośrednim. Owo zapośredniczenie ma podwójne znaczenie. Po pierwsze, jeżeli chodzi o podmiot zmieniający, bo przekształca nie tyle pedagog, ile sama społeczność poprzez wykorzystanie własnych sił ludzkich (jednostkowych i zbiorowych). Po drugie, w sensie koncepcyjnym, bowiem model wychowania czy koncepcja przekształceń nie jest odgórna, nie pochodzi od pedagoga, ale jest wytworem lokalnych kultur.

\section{Rewitalizacja polityczna (model emancypacyjny)}

U podstaw emancypacyjno-krytycznego nurtu w myśleniu o rewitalizacji miasta leży założenie możliwości rozwoju jego infrastruktury w sposób osłabiający czy znoszący instytucjonalne, prawne, polityczne, ekonomiczne czy społeczno-kulturowe bariery, by urealnić ideał miasta demokratycznego, społecznie sprawiedliwego i dbającego o interesy zróżnicowanych grup mieszkańców ${ }^{38}$. Zwykle

${ }^{36}$ M. Mendel, Pedagogika miejsca i animacja..., s. 28.

${ }^{37}$ Maria Mendel w tym kontekście używa figury retorycznej wspólnie zamieszkiwanego „pokoju” zaczerpniętej od Jacquesa Rancière (por. M. Mendel, Wspólny Pokój Gdańsk. Miejskie modi co-vivendi w badaniu metoda Krytycznej Historii Miasta, [w:] M. Mendel (red.), Miasto jako wspólny pokój. Gdańskie modi co-vivendi, Gdańskie Towarzystwo Naukowe. Instytut Kultury Miejskiej, Gdańsk 2015). Warto zauważyć, że sama autorka lokuje swoją koncepcję w grupie podejść krytycznych, ponieważ jednak dominują w nim wątki konstruktywne, a nie demistyfikacje ukrytych mechanizmów rządzenia, zdecydowaliśmy się przypisać ją do modelu interpretatywnego. Mamy oczywiście świadomość, że ogniskując się na innych aspektach tego podejścia, choćby innych tekstach z przywołanego tomu, mogłoby ono z powodzeniem wypełnić założenia krytyczno-emancypacyjne.

${ }^{38}$ Można tutaj zauważyć analogię do sudyscypliny socjologicznej - krytycznej teorii miasta (critical urban theory) (N. Brenner, What is critical urban theory?, "City" 2009, 13, s. 198-207; N. Brenner, P. Marcuse, M. Mayer, Cities for people, not for profits: An introduction, [w:] N. Brenner, P. Marcuse, M. Mayer (red.), Cities for people, not for profit: Critical urban theory and the right to the city, Routledge, New York 2011, s. 1-11; D. Harvey, The right to the city, "International Journal of Urban and Regional Research" 2003, 27, s. 939-994), która, hołdując ideałom sprawiedliwości i równości społecznej, w swoich badaniach koncentruje się na sposobach ujawniania 
jednak pierwszym, niestety dla niektórych i ostatnim, etapem refleksji krytycznej jest ujawnienie wysublimowanych, ukrytych, rozproszonych czy bezosobowych mechanizmów władzy. W małych sąsiedztwach wielkomiejskich, w szczególności sposobach społecznej aranżacji i dystrybucji przestrzeni, jak w soczewce ogniskują się znoszące się interesy różnych grup społecznych, z których wybrane (ideologicznie, kulturowo, etnicznie, aksjologicznie etc. bliższe dominującym dyskursom) są uprzywilejowane.

Silna pozycja podejścia krytyczno-emancypacyjnego w teoretycznej pedagogice akademickiej, a szczególnie w dyskursie edukacyjnym, nie wydaje się przekładać na transformatywną sprawczość podejść krytycznych w pedagogicznych badaniach społeczności lokalnych oraz konsekwentnych im koncepcjach działania. Wskazuje to ważny dla pedagogiki społecznej kierunek rozwoju i poszukiwań, który badała m.in. Anita Gulczyńska. Wygenerowana przez nią koncepcja sąsiedztwa społecznie niejednorodnego (efekt kilkuletniego społecznie zaangażowanego badania jednego z łódzkich zubożałych sąsiedztw kamienicznych) może inspirować procesy diagnozy, konceptualizacji i realizacji zmian rewitalizacyjnych prowadzonych z wrażliwością krytyczną, zarysowując w języku tej perspektywy rolę pedagogów społecznych ${ }^{39}$.

Sąsiedztwem społecznie niejednorodnym określana jest tutaj taka przestrzeń komunikacyjna, która jest tworzona w związku z terytorium zamieszkiwanym przez grupy mające różny poziom wpływu na nie. Nierówność ta prowadzi do konfliktów pomiędzy mieszkańcami w trakcie społecznej dystrybucji przestrzeni. W efekcie pogłębiają się i tak znaczne dysproporcje władzy pomiędzy nimi.

W przypadku referowanych tu badań nierównemu podziałowi władzy sprzyjały różnice między mieszkańcami ujawniające się w trzech aspektach:

- znaczeniu sąsiedztwa dla mieszkańców;

- rodzaju prawa do mieszkania rezydentów sąsiedztwa;

- perspektywie poznawczej, w kategoriach której interpretują oni fakty z otoczenia.

Ze względu na znaczenie sąsiedztwa dla jego mieszkańców przyporządkować ich można do jednej z dwóch kategorii - uczestników albo nieuczestników. Dla

się przejawów nierówności w społecznościach miejskich i miastach jako takich. Powstała ona na drodze kontestacji perspektywy szkoły chicagowskiej (dominującej w socjologii miasta), w której rodowodzie upatruje się przesłanek neoliberalnej koncepcji miasta. Reprezentujący ją badacze nie dochodzą logiki zmian miast w czasie czy dynamiki życia społecznego i procesów powstawania społeczności miejskich, ale pożytkując twórczo przesłanki szkoły frankfurckiej, postrzegają miasto jako przestrzeń obciążoną ideologicznie, politycznie etc. (T. L. Green, M. A. Gooden, Transforming Out-of-School Challenges Into Opportunities: Community Schools Reform in the Urban Midwest, "Urban Education" 2014, vol. 49 (8), s. 935).

39 Szerzej w: A. Gulczyńska, „Chłopaki z dzielnicy”..., s. 67-86; taż, Upetnomocnienie (empowerment) młodzieży z sqsiedztw społecznie niejednorodnych. Diagnoza i koncepcja działania, [w:] A. Gulczyńska, M. Granosik (red.), Empowerment w pracy socjalnej..., s. 149-152. 
uczestników sąsiedztwo było przestrzenią społecznie znacząco kontekstualizującą ich biografie. Dla nieuczestników jedynie przestrzenią komunikacji fizycznej - częścią drogi do pracy, miejscem garażowania samochodu etc. $Z$ tych powodów prowadzone przez tych drugich interakcje sąsiedzkie wyrażały jedynie celowość instrumentalna, nie zaś osobowa.

Podnajemcy czynszowi i właściciele mieszkań to kategorie wyrażające zróżnicowanie mieszkańców w zakresie posiadanego prawa do mieszkania. Pierwsi, jedynie wynajmujący mieszkanie od miasta, byli formalnie wykluczeni ze wspólnoty mieszkaniowej decydującej o zmianach w sposobie zagospodarowania terytorium sąsiedztwa, pomimo iż to oni ożywiali ją życiem społecznym. Podejmowane na zebraniach uchwały nie uwzględniały społecznego podziału przestrzeni. Nierówny dostęp do formalnej władzy w miejscu zamieszkania oraz odmienność znaczeń przypisywanych przestrzeni sąsiedztwa przekładały się na odmienność oczekiwań wobec niej, czego konsekwencją były zaburzenia komunikacji pomiędzy reprezentantami tych grup. Antagonizmy pomiędzy nimi umacniała ponadto odmienność perspektyw poznawczych ${ }^{40}$. Mieszkańcy tego samego sąsiedztwa różnie rozumieli otaczający ich świat i tym samym elementom rzeczywistości przypisywali inne znaczenia. $Z$ tej perspektywy (poznawczej) można było wyodrębnić dwie kategorie mieszkańców: swoich (czyli dzielnicę) ${ }^{41}$ i „obcych”.

W tej sytuacji uczestnicy, wykluczeni z decyzji administracyjnych dotyczących sąsiedztwa, a identyfikujący siebie jako wrogów frajerstwa i policji, którzy szacunek na dzielnicy zyskuja, kiedy się nie daja, dzielili małe terytorium sąsiedztwa z uprzywilejowaną mniejszością, oczekującą szacunku do decyzji administracyjnych, a w sytuacji ich nieprzestrzegania odwołującą się do policji, administracji czy innych środków nacisku. W takim kontekście społecznie naturalną cechą codziennej komunikacji stał się konflikt. Szczególnie silnie manifestował się on w interakcjach grup dzieci i młodzieży z tymi, którzy nie widzieli dla nich miejsca w sąsiedztwie.

Analogicznych procesów można się spodziewać w zrewitalizowanych sąsiedztwach, szczególnie gdy jednym z działań jest zasiedlanie zubożałych sąsiedztw reprezentantami klasy średniej, uzasadniane celami edukacyjnymi ${ }^{42}$.

\footnotetext{
${ }^{40}$ Perspektywa poznawcza wyrażona jest tutaj odnoszeniem się w codziennym działaniu do intersubiektywnie wynegocjowanej i podzielanej struktury znaczeń. W analizie symbolicznej warstwy działania mieszkańców sąsiedztwa niejednorodnego Gulczyńska zauważa pewne analogie do koncepcji świata społecznego Anselma Straussa, którego uczestnicy podobnie rozumieją świat, podobnie interpretują fakty i podobnie na nie reagują. Szerzej w: A. Kacperczyk, Zastosowanie koncepcji spolecznych światów w badaniach empirycznych, [w:] E. Hałas, K. Konecki (red.), Konstruowanie jaźni i społeczeństwa. Europejskie warianty interakcjonizmu symbolicznego, Wydawnictwo Naukowe Scholar, Warszawa 2005.

${ }^{41}$ Dzielnica jest kodem 'in vivo', a więc pojęciem zapożyczonym wprost $\mathrm{z}$ języka uczestników badania. Kody 'in vivo' stanowią kluczowe pojęcia koncepcji sąsiedztwa społecznie niejednorodnego, a ich obecność w niniejszym tekście sygnalizowana jest kursywą.

${ }^{42} \mathrm{U}$ podstaw takich działań odnaleźć można analogię do popularnego w Stanach Zjednoczonych modelu wyjaśniania wpływu zdegradowanych sąsiedztw na socjalizację ich mieszkańców
} 
Sąsiedztwa rewitalizowane z założenia są społecznie niejednorodne. $\mathrm{W}$ ich społeczną kompozycję wpisana jest mniejszość uprzywilejowana pod względem administracyjnym, ekonomicznym i kulturowym oraz nieuprzywilejowana większość. Interesy i preferencje tej drugiej grupy zwykle nie są w wystarczającym stopniu brane pod uwagę podczas projektów rewitalizacyjnych. Koncepcja sąsiedztwa społecznie niejednorodnego może więc stanowić inspirującą wykładnię w definiowaniu ram emancypacyjno-krytycznie zorientowanej roli pedagogów społecznych w procesach rewitalizacji. Celem ich pracy byłoby równoważenie rozwoju małych przestrzeni miejskich, oparte o partycypację wszystkich podmiotów, którzy jednocześnie byliby przygotowywani do otwarcia się na doświadczenie „,spotkania z innym", by uzgadniać lokalny ład społeczny na wspólnie wypracowanych warunkach. Krytyczno-emancypacyjnie zorientowany pedagog społeczny stałby na straży szacunku dla odmienności i podmiotowego traktowania wszystkich grup mieszkańców - tych „Zadomowionych” i tych nowych - równoważąc strukturalnie, kulturowo czy prawnie legitymizowane uprzywilejowanie tych drugich. Będąc uwrażliwionym na przejawy nadużywania władzy w procesie organizacji wspólnej przestrzeni, będzie dbał o równouprawnienie w planowanych zmianach perspektywy każdej z grup użytkujących przestrzeń, kontestując projekty narzucające zewnętrzne modele organizacji, infrastruktury czy estetyki. Pomijanie perspektywy „mniejszości” (lub defaworyzowanej większości) jest w tym ujęciu elementem procesu jej społecznego wykluczania. Przestrzeń codziennego życia członków społeczności lokalnej zorganizowanej z szacunkiem jedynie do wybranych grup jej użytkowników „ożywiać” będą głównie konflikty wynikające z odgórnej akceptacji jedynie wybranych sposobów dystrybucji wspólnie zamieszkiwanego terytorium i penalizowaniu rozwiązań alternatywnych, co nie ma nic wspólnego z ideą rewitalizacji.

Biorąc to pod uwagę, już diagnoza prowadzona na rzecz rewitalizacji powinna odkrywać wymiary zróżnicowania mieszkańców, by antycypować sposoby ujawniania się ich w codziennym życiu społecznym zrewitalizowanych sąsiedztw i włączyć tę wiedzę w koncepcję zmian. Już w samej organizacji społecznych konsultacji ujawniać się może ukryta celowość wypracowania zgody na zaplanowany odgórnie proces, zaakceptowania przez mieszkańców tego, co już zostało na innym szczeblu uzgodnione, a nie faktycznej partycypacji społecznej

\footnotetext{
- modelu kolektywnej socjalizacji. Przyczyn negatywnego wpływu sąsiedztwa badacze tematu upatrują w nieobecności mieszkańców „klasy średniej”, jako filaru wartości i ostoi pozytywnych wzorów osobowych i rodzinnych, co skłania młodych mieszkańców do naśladowania dorosłych stanowiących negatywne wzorce osobowe (J. Brooks-Gun, G. Duncan, P. K. Klebanov, N. Sealand, Do neighborhoods influence child and adolescent development?, "American Journal of Sociology" 1993, 99 (2); C. Jencks, S. E. Mayer, The social consequences of growing up in a poor neighborhood, [w:] L. Lynn, M. McGeary (red.), Inner-city poverty in the United States, National Academy Press, Washington 1990).
} 
zainteresowanych stron. Cały proces wprowadzania zmian powinien na wszystkich etapach uwzględniać działania równoważące dysproporcje władzy i wiedzy, ze szczególną troską o uważnienie perspektywy grup nieuprzywilejowanych. Rewitalizacja lokalnych przestrzeni nie tylko powinna odpowiadać na doświadczenia nierówności w miejskich społecznościach lokalnych, lecz także być planowaną i organizowaną ze świadomością znaczenia tych nierówności dla efektów i trwałości wprowadzanych zmian.

Inspiracje do działań wyrażających tak zarysowaną rolę pedagoga społecznego w procesach rewitalizacji odnajdujemy w koncepcji upełnomocniającej pracy społecznej w sąsiedztwie społecznie niejednorodnym ${ }^{43}$. Niezależnie od tego, że powstawała jako społeczno-pedagogiczna odpowiedź na zrekonstruowany badaniem proces wykluczania społecznego młodzieży z sąsiedztwa noszącego znamiona społecznej niejednorodności, zaproponowane formy działań wykraczają poza jedną kategorię wieku mieszkańców. Są bowiem odpowiedzią na procesy społecznego wykluczania w sąsiedztwach, gdzie ścierają się alternatywne perspektywy, sprzeczne interesy i odmienne style życia, co wymaga działań zorientowanych na ${ }^{44}$ :

- pomostowanie, rozumiane jako zapobieganie czy udrażnianie zaburzonej komunikacji w sąsiedztwie i wspieranie wzajemnej, obustronnej adaptacji mieszkańców reprezentujących grupy uprzywilejowane i nieuprzywilejowane oraz nauczanie negocjacji ${ }^{45}$;

- rzecznictwo społeczne, polegające na reprezentowaniu interesów klientów przed posiadającymi władzę jednostkami czy strukturami społecznymi oraz uważnianiu głosu mniejszości w dyskursach od lokalnego, poprzez samorządowy do publicznego.

Jak widać, w takim społeczno-pedagogicznym rozumieniu, rewitalizacja nigdy nie ogranicza się do pracy ze społecznością lokalną, ale dotyczy również pracy nad społeczeństwem, które zaniedbanej społeczności musi dać szansę ożywienia/odrodzenia na bazie jej potencjału i na gruncie (glebie) jej kultury lokalnej. Często przyczyną wykluczenia społecznego jest pozbawienie społeczności możliwości aktywnego uczestnictwa w głównych dyskursach społecznych na własnych i równych zasadach.

${ }^{43}$ Koncepcja upełnomocniającej pracy w sąsiedztwach społecznie niejednorodnych została zaprezentowana w trzech publikacjach, których chronologiczny porządek oddaje stopień zaawansowania namysłu i uszczegółowienie jego kluczowych kategorii: A. Gulczyńska, Empowering interventions in the course of a socially engaged research. An example of participatory study on youth from an unprivileged neighborhood in Lódź, "Socialinis Darbas. Patirtis ir Metodai/ Social Work. Experience and Method” 2012, 9 (1), s. 89-112; taż, „Chłopaki z dzielnicy”...; taż, Upetnomocnienie (empowerment) młodzieży..., s. 147-160.

${ }^{4}$ Szerzej w: A. Gulczyńska, „Chłopaki z dzielnicy”..., s. 249; taż, Upetnomocnienie (empowerment) młodzieży..., s. 157-158.

${ }^{45}$ Działaniami pomostującymi mogłyby być projekty oparte na partycypacji, wspólnym działaniu na rzecz sąsiedztwa z dbałością o priorytety i cele wszystkich grup mieszkańców. 


\section{Kilka uwag z perspektywy krytycznej na zakończenie}

W rozdziale poświęconym ożywianiu przestrzeni życia trudno nie wspomnieć o współczesnych ograniczeniach i problemach rewitalizacji oraz postulowanych wcześniej działań. Należałoby przy tym dodać, że podejmowane dalej kwestie mogą uchodzić za wątpliwe lub ryzykowne jedynie z pewnych perspektyw, z innych będąc nieproblematycznymi.

Pierwsza kwestia, która szczególnie dotyka rewitalizację, nazywaną tu społeczną, ale i częściowo humanistyczną, jest włączanie grup wykluczonych i ich partycypacja. Myślenie w kategoriach włączania zakłada teoretyczny model społeczeństwa konstruowany przez większość, która uczestniczy w (prawdziwej) kulturze, osiagnęła więcej, żyje lepiej, zachowuje się godniej. W pewnym uproszczeniu można podsumować to jako poruszanie się w ramach wartości, stylu życia, wrażliwości klasy średniej. Rewitalizacja ma umożliwić outsiderom przyłączenie się do tak zdefiniowanego społeczeństwa sukcesu (często raczej nadziei na sukces), stąd podkreśla się znaczenie wymiaru ekonomicznego, uczestnictwa w (wysokiej) kulturze oraz edukacji. Nie bez racji można jednak w tym wydawałoby się głęboko humanitarnym akcie podzielenia się z grupami zmarginalizowanymi „receptą na sukces” doszukiwać się kolonizacji tych, których kultura (ani wysoka, ani oświecona) nie zdołała wytworzyć dostatecznie respektowanego dyskursu. W jeszcze bardziej krytycznej perspektywie to nic innego jak próba objęcia tych grup kontrolą, wysublimowana forma władzy już nie tylko nad ciałem, ale i duszą, czyli sposobem interpretowania świata i zachodzących w nim procesów, systemem wartości, stylem życia etc. ${ }^{46}$

Kolejny problem dotyczy kategorii kultury lokalnej i społeczności lokalnej w kontekście procesów globalizacyjnych, w tym e-globalizacji. W pewnym sensie cała koncepcja rewitalizacji, a więc podejmowanie działania na wyraźnie zakreślonej przestrzeni jako wyodrębnionej - również w sensie społecznym - części miasta jest rzec można archaiczna. Ostatnie dziesiątki lat to przecież intensywny rozwój technik komunikacyjnych, osłabianie więzi sąsiedzkich, za to wzrost znaczenia relacji pośrednich. W konsekwencji „zamierają” podwórka, bo młodzi ludzie komunikują się przez social media, co nie wymaga opuszczania pokoju, a jeżeli już z niego wychodzą, to żeby spotkać się ze znajomymi z różnych stron miasta albo pójść do szkoły, jednak już nie tej samej, rejonowej, bo rodzice posyłają dzieci do szkół najlepiej odnajdujących się w rankingach. Powrót do relacji sąsiedzkich i modelu wspólnoty lokalnej sprzed stu lat

${ }^{46}$ Zagadnienie to w odniesieniu do badań partycypacyjnych w: M. Granosik, Discursive Participation of Social Work Research - A Critical Perspective, [w:] D. Paturel (red.), Recherche en travail social: les approaches participatives, CHAMP SOCIAL, Nimes 2014, natomiast w odniesieniu do pracy socjalnej w: tenże, Pogranicza pedagogizacji - refleksje o wielowymiarowości procesów instytucjonalizacji na przykładzie pracy socjalnej, „Societas/Communitas” 2013, nr 2 (16). 
jest chyba niemożliwy. Nie sprzyja też temu zachodząca w miastach segregacja ekonomiczna oparta choćby na zróżnicowanych wartościach gruntów, bowiem integrowanie społeczności lokalnej oznaczałoby integrowanie ludzi o podobnym profilu (statusie) społecznym, co zamiast być początkiem budowania wspólnoty różnorodności, raczej przyczyniłoby się do nasilenia partykularnych roszczeń zintegrowanych (ale tylko ze sobą i często przeciw innym) homogenicznych grup społecznych. Jeżeli wspólnota lokalna w sensie tradycyjnym jeszcze gdzieś istnieje, to przede wszystkim w obszarach zamieszkiwanych przez grupy defaworyzowane. Są to też miejsca, gdzie przetrwały chyba ostatnie podwórka. Paradoksalnie, rewitalizacja więzi społecznych powinna być podejmowana przede wszystkim w zamkniętych i strzeżonych apartamentowcach, gdzie nie tylko nie ma podwórek (w zamian są ogrody z tropikalną roślinnością), ale nawet ławek. W praktyce jednak architekci, specjaliści od zarządzania i coraz częściej pedagodzy, tam właśnie mieszkający, „urządzają świat” tym, którzy - w sensie społecznościowym - jeszcze go tak nie zniszczyli. Co ciekawe, w praktycznych realizacjach rewitalizacji często pierwszą jej ofiarą są właśnie podwórka, które po przebudowie, choć piękne z pewnej perspektywy, tracą dawny urok miejsca spotkań $^{47}$. Zupełnie analogicznie przedstawia się kwestia kultury lokalnej. Wszyscy oglądamy te same kanały telewizyjne, kupujemy te same meble, to samo nam się podoba. W epoce pozornego jak się okazuje indywidualizmu paradoksalnie stajemy się ofiarami masowej produkcji i zunifikowanego stylu życia. Mamy coraz szersze horyzonty myślowe, przejmujemy się problemami „makro”, nie widząc często tego, co tuż obok.

Ostatnia kwestia, podjęta tutaj jedynie symbolicznie, dotyczy wirtualizacji współczesnej rzeczywistości, która jest już faktem, a jednak w procesach rewitalizacyjnych nie jest zupełnie brana pod uwagę. Coraz większa część naszej aktywności ekonomicznej (kupowanie, sprzedawanie, znacznie częściej także praca), społecznej (fora, znajomi), wolnoczasowej (rozrywka, edukacja, kontakt ze sztuką) przenosi się do Internetu. Sieć ta ma swoją architekturę, elity symboliczne, reguły, przestępczość, miejsca o różnej funkcjonalności, właściwie wszystkie cechy przestrzeni fizycznej. Rewitalizacja przyszłości musi obejmować również przestrzeń wirtualną, a kto wie, może ten właśnie wymiar będzie jej podstawowym obszarem. Pozostając w kręgu rozważań nad miejscami, gdzie rewitalizacja nie dociera, trzeba wspomnieć wieś - przestrzeń tradycyjnie bardzo ważną dla pedagogiki społecznej. Kiedyś z racji jej zacofania kulturalno-oświatowego, dzisiaj z uwagi na nieco inny typ problemów i zdecydowanie łatwiejszy proces integracji terytorialnej. Przenoszenie miejsca zamieszkania przez część ludności

${ }^{47}$ Ciekawe, również krytyczne, refleksje na ten temat w: W. Jarczewski, M. Huculak, K. Janas (red.), Rewitalizacja podwórek, Instytut Rozwoju Miast, Kraków 2013. W publikacji tej pokazano, że geografia jest jedną z tych dyscyplin, które coraz wyraźniej dostrzegają ludzki wymiar procesów zmian przestrzeni lokalnej. 
miejskiej do okolicznych wiosek czyni też tę społeczność zróżnicowaną (prawdopodobnie w odróżnieniu od gettoizujących się miast).

Wydaje się, że wiele sygnalizowanych tu problemów traci na znaczeniu, jeżeli przyjąć interpretatywną lub emancypacyjną perspektywę społeczno-pedagogiczna, bowiem zakres i obszar działań rewitalizacyjnych pokrywałby się z „mapą” spraw i miejsc istotnych dla samych mieszkańców. Istnieje jednak pewne ryzyko, że ich wyobrażenie „miejsca do życia” jest nie do zaakceptowania przez dysponentów środków i dominujących dyskursów formatujących działania rewitalizacyjne. Jakby bowiem nie patrzeć, rewitalizacja jest problemem polityczno-klasowym i wiąże się z poważnym ryzykiem manifestacji bezdyskusyjnej dominacji klasy średniej ${ }^{48}$. Zmierzenie się z własnymi ograniczeniami będzie chyba największym wyzwaniem dla wszystkich zaangażowanych w ożywianie przestrzeni życia.

Pomijając być może dyskusyjne kwestie dyskursowych i politycznych uwikłań procesów rewitalizacyjnych, nie mamy jednak wątpliwości, a potwierdza to również stuletnia historia pedagogiki społecznej, że bez uwzględnienia przekształceń środowiska wychowawczego nie ma możliwości skutecznego i trwałego rewitalizowania jakiejkolwiek przestrzeni. Jeżeli olbrzymie nakłady finansowe i organizacyjne mają przynieść efekt, muszą przenosić się na kolejne pokolenia, czyli powinny być wkomponowane w złożone, powolne i często nieoczywiste procesy wychowawcze. Jak pokazuje dorobek pedagogiki społecznej, nie osiąnnie się tego poprzez konsultacje społeczne ani nawet najlepsze ankiety, lecz tylko poprzez wysiłek zrozumienia lokalnej kultury oraz autentyczną i zaangażowaną obecność (nie ingerencję).

\section{Bibliografia}

Brenner N., What is critical urban theory?, "City" 2009, 13.

Brenner N., Marcuse P., Mayer M., Cities for people, not for profits: An introduction, [w:] N. Brenner, P. Marcuse, M. Mayer (red.), Cities for people, not for profit: Critical urban theory and the right to the city, Routledge, New York 2011.

Brooks-Gun J., Duncan G., Klebanov P. K., Sealand N., Do neighborhoods influence child and adolescent development?, "American Journal of Sociology” 1993, 99 (2).

Chmielowski B., Pałac młodzieży jako placówka wychowania (Wychowanie do wczasów w placówce typu Pałac Młodzieży), Gabinet Metodyczny - Pałac Młodzieży w Katowicach, Katowice 1971.

Cichosz M., Pedagogika społeczna w Polsce w latach 1945-2005, Wyd. Adam Marszałek, Toruń 2006 .

\footnotetext{
${ }^{48}$ Sama dyskusja wokół programów rewitalizacyjnych jest formatowana wyobrażeniami klasy średniej, czyli formułą „konsultacji społecznych” czy „demokracji deliberatywnej”. Taka formuła eliminuje większość istotnych głosów, które są w sposób nieodpowiedni - z dominującej perspektywy „klasy średniej” - wyrażone (np. krzykiem, poprzez atak fizyczny lub poprzez nieobecność) albo pojawiają się po czasie (ponieważ czasem rządzą harmonogramy finansowe, czyli zwykle wszystko dzieje się w ostatnim momencie). Sposób komunikowania się ze społecznością czy szerzej - intersubiektywnego jej rozumienia (nie zaś prostego uzyskiwania odpowiedzi na pytania) jest istotnym i trudnym zagadnieniem diagnostyki interpretatywnej.
} 
Ciczkowska-Giedziun M., Dzieci i młodzież w osiedlu miejskim: diagnoza i rozwiqzania modelowe, Olsztyńska Szkoła Wyższa im. Józefa Rusieckiego, Olsztyn 2002.

Dykcik W., Stanisława Kowalskiego (1904-1991) koncepcja doskonalenia systemu wychowawczego w środowisku, [w:] S. Kawula (red.), Pedagogika społeczna. Dokonania - aktualność - perspektywy, Wyd. Adam Marszałek, Toruń 2001.

Granosik M., Diagnostyka interpretatywna: między jakościowq metodologia i praktykq, [w:] M. Szpunar (red.), Badania w pracy socjalnej, ANWI, Gdańsk 2015.

Granosik M., Discursive Participation of Social Work Research - A Critical Perspective, [w:] D. Paturel (red.), Recherche en travail social: les approaches participatives, CHAMP SOCIAL, Nimes 2014.

Granosik M., Praca socjalna $w$ perspektywie interpretatywnej: teoria, diagnoza, dziatanie, [w:] A. Skowrońska (red.), Nowe ujęcia znanych problemów pomocy społecznej, IRSS, Warszawa 2013.

Granosik M., Pogranicza pedagogizacji - refleksje o wielowymiarowości procesów instytucjonalizacji na przyktadzie pracy socjalnej, ,Societas/Communitas” 2013, nr 2 (16).

Granosik M., Gulczyńska A., Empowerment i badania w pracy socjalnej, [w:] A. Gulczyńska, M. Granosik (red.), Empowerment w pracy socjalnej: praktyka i badania partycypacyjne, seria Nowa Praca Socjalna, Centrum Rozwoju Zasobów Ludzkich, WYG International, Warszawa 2014.

Green T. L., Gooden M. A., Transforming Out-of-School Challenges Into Opportunities: Community Schools Reform in the Urban Midwest, "Urban Education" 2014, vol. 49 (8).

Gulczyńska A., ,, Chłopaki z dzielnicy”. Studium społeczno-pedagogiczne z perspektywy interakcyjnej, Wydawnictwo Uniwersytetu Łódzkiego, Łódź 2013.

Gulczyńska A., Empowering interventions in the course of a socially engaged research. An example of participatory study on youth from an unprivileged neighborhood in Eódź, "Socialinis Darbas. Patirtis ir Metodai/Social Work. Experience and Method" 2012, 9 (1).

Gulczyńska A., Upetnomocnienie (empowerment) młodzieży z sqsiedztw społecznie niejednorodnych. Diagnoza i koncepcja działania, [w:] A. Gulczyńska, M. Granosik (red.), Empowerment w pracy socjalnej: praktyka i badania partycypacyjne, seria Nowa Praca Socjalna, Centrum Rozwoju Zasobów Ludzkich, WYG International, Warszawa 2014.

Gulczyńska A., Granosik M. (red.), Empowerment w pracy socjalnej: praktyka i badania partycypacyjne, seria Nowa Praca Socjalna, Centrum Rozwoju Zasobów Ludzkich, WYG International, Warszawa 2014.

Harvey D., The right to the city, "International Journal of Urban and Regional Research" 2003, 27.

Jarczewski W., Huculak M., Janas K. (red.), Rewitalizacja podwórek, Instytut Rozwoju Miast, Kraków 2013.

Jencks C., Mayer S. E., The social consequences of growing up in a poor neighborhood, [w:] L. Lynn, M. McGeary (red.), Inner-city poverty in the United States, National Academy Press, Washington 1990.

Kacperczyk A., Zastosowanie koncepcji spotecznych światów w badaniach empirycznych, [w:] E. Hałas, K. Konecki (red.), Konstruowanie jaźni i społeczeństwa. Europejskie warianty interakcjonizmu symbolicznego, Wydawnictwo Naukowe Scholar, Warszawa 2005.

Kaczmarek J., Geobiografia - historie życia a studia nad migracjami, „Acta Universitatis Lodziensis. Folia Geographica Socio-Oeconomica" 2004, nr 5.

Kamiński A., Funkcje pedagogiki społecznej, PWN, Warszawa 1973.

Kamiński A., Wstęp, [w:] H. Radlińska (red.), Pedagogika społeczna, Ossolineum, Wrocław 1961.

Kawula S., Pedagogika spoleczna i jej wyzwania u progu XXI w., [w:] E. Marynowicz-Hetka, Pedagogika społeczna. Podręcznik akademicki, t. 2, PWN, Warszawa 2007.

Lepalczyk I., Pawłowska W., Teoria i organizacja pracy środowiskowej w osiedlu mieszkaniowym, TWWP, Warszawa 1970. 
Lepalczyk I. (red.), Stowarzyszenia społeczne jako środowisko wychowawcze, PWN, Łódź 1973. Marynowicz-Hetka E., Szkoła jako instytucja pomocy w rozwoju, „Chowanna” 1989, z. 1.

Marynowicz-Hetka E., Piekarski J., Urbaniak-Zając D. (red.), Pedagogika społeczna i praca socjalna. Przeglad stanowisk i komentarze, Wyd. Śląsk, Katowice 1998.

Mendel M., Pedagogika miejsca i animacja na miejsce wrażliwa, [w:] M. Mendel (red.), Pedagogika miejsca, Wyd. Naukowe DSWE, Wrocław 2006.

Mendel M., Wspólny Pokój Gdańsk. Miejskie modi co-vivendi w badaniu metoda Krytycznej Historii Miasta, [w:] M. Mendel (red.), Miasto jako wspólny pokój. Gdańskie modi co-vivendi, Gdańskie Towarzystwo Naukowe. Instytut Kultury Miejskiej, Gdańsk 2015.

Mendel M., Wstęp, [w:] M. Mendel (red.), Pedagogika miejsca, Wyd. Naukowe DSWE, Wrocław 2006.

Mendel M. (red.), Pedagogika miejsca, Wyd. Naukowe DSWE, Wrocław 2006.

Męczkowska A., Locus educandi. Wokót problematyki miejsca w refleksji pedagogicznej, [w:] M. Mendel (red.), Pedagogika miejsca, Wyd. Naukowe DSWE, Wrocław 2006.

Radlińska H., Pedagogika społeczna, Zakład Narodowy im. Ossolińskich, Wrocław 1961.

Radlińska H., Z dziejów pracy społecznej i oświatowej, Zakład Narodowy im. Ossolińskich, Wroclaw 1964.

Radlińska H. (red.), Społeczne przyczyny powodzeń i niepowodzeń szkolnych, Nasza Księgarnia, Warszawa 1937.

Ricouer P., Egzystencja i hermeneutyka: rozprawy o metodzie, thum. E. Bieńkowska, Instytut Wydawniczy PAX, Warszawa 1975.

Skrzypczak B., W kierunku społecznościowej pracy socjalnej. Edukacyjno-środowiskowe determinanty interwencji publicznej, CAL, Warszawa 2014.

Szkudlarek T., Media. Szkic z filozofii i pedagogiki dystansu, Oficyna Wydawnicza „Impuls”, Kraków 1999.

Szmagalski J., Teoria pracy socjalnej a ideologia i polityka społeczna - przykład amerykański, Wydawnictwo Żak, Warszawa 1996.

Śnieżyński M., Działalność opiekuńczo-wychowawcza w osiedlu, Wydawnictwa Szkolne i Pedagogiczne, Warszawa 1981.

Trempała E., Integracja podstawowych środowisk wychowawczych a rezultaty pracy pedagogicznej szkoły, Państwowe Wydawnictwo Naukowe, Warszawa 1969.

Trempała E., Pedagogiczna działalność wychowawców nieprofesjonalnych w środowisku lokalnym, Wyższa Szkoła Pedagogiczna w Bydgoszczy, Bydgoszcz 1988.

Trempała E., Balcerek M., Winiarski M. (red.), Opieka $i$ wychowanie w osiedlu mieszkaniowym, Wydawnictwa Szkolne i Pedagogiczne, Warszawa 1981.

Urbaniak-Zając D., Koncepcja ,'środowiska” w teorii pedagogiki społecznej Aleksandra Kamińskiego a idea ,Lebenswelt”, [w:] E. Marynowicz-Hetka, H. Kubicka, M. Granosik (red.), Aleksander Kamiński i jego twórczość pedagogiczna. Dyskusja o przeszłości wobec teraźniejszości i przyszłości, Wydawnictwo Uniwersytetu Łódzkiego, Łódź 2004.

Wilk T., Rewitalizacja społeczna poprzez wspótczesna sztuke teatralna $w$ ocenie reprezentantów (twórców i odbiorców) sztuki dramatycznej Legnicy, Nowej Huty i Watbrzycha, Wydawnictwo Uniwersytetu Śląskiego, Katowice 2010.

Wołczyk J., Z badań nad zbiorczq szkoła gminna, Zeszyty Naukowe nr 18 „Prace Wydziału Pedagogicznego", WSP, Szczecin 1976.

Wołczyk J., Winiarski M. (red.), Szkoła otwarta-rzeczywistość i perspektywy, PWN, Warszawa 1976.

Znaniecki F., Socjologia wychowania, PWN, Warszawa 1973.

Żebrowski J., Wspótczesny wymiar animacji społeczno-wychowawczej i kulturalnej, [w:] J. Żebrowski (red.), Animacja kulturalna i społeczno-wychowawcza w środowiskach lokalnych, GTN, Gdańsk 2003.

Żukiewicz A., Wprowadzenie do ontologii pracy społecznej. Odniesienia do społeczno-pedagogicznej refleksji Heleny Radlińskiej, Wyd. UP, Kraków 2009. 